Original Research Article

\title{
Comparative evaluation of the effect of Ocimum sanctum and metformin on serum lipid profile in high fat diet fed diabetic rats
}

\author{
Shailendra Mishra ${ }^{1}$, Quazi Shahir Ahmed ${ }^{2 *}$, Kauser Sayedda ${ }^{2}$
}

\begin{abstract}
${ }^{1}$ Department of Pharmacology, Integral Institute of Medical Sciences, Lucknow, Uttar Pradesh, India ${ }^{2}$ Department of Pharmacology, IIMS\& R, Integral University, Uttar Pradesh, India
\end{abstract}

Received: 11 January 2019

Accepted: 07 February 2019

*Correspondence to: Dr. Quazi Shahir Ahmed, Email: quazi800@yahoo.com

Copyright: (C) the author(s), publisher and licensee Medip Academy. This is an openaccess article distributed under the terms of the Creative Commons Attribution NonCommercial License, which permits unrestricted noncommercial use, distribution, and reproduction in any medium, provided the original work is properly cited.

\begin{abstract}
Background: Dyslipidaemia is an important risk factor for development of macrovascular complications in type 2 diabetes mellitus. Ocimum sanctum (OS) and metformin have shown to have antihyperlipidaemic effects. The present study was undertaken to evaluate the effects of OS and Metformin on body weight \& plasma lipid levels of high fat diet fed diabetic rats

Methods: Total of 30 male wistar rats (100-150gm) were obtained. Animals were fed with a high fat diet throughout the study (6 weeks). Diabetes was induced by using single intra-peritoneal injection of Streptozotocin $50 \mathrm{mg} / \mathrm{kg}$ at the end of 4 weeks. Diabetic rats were divided into groups of 6 each and treated as follows: Group 1- Diabetic control, was given vehicle orally. Group 2- O.S. ethanolic extract $100 \mathrm{mg} / \mathrm{kg}$ body weight orally for 14 days. Group 3- O.S. ethanolic extract $200 \mathrm{mg} / \mathrm{kg}$ body weight orally for 14 days. Group 4- Metformin $100 \mathrm{mg} /$ day for 14 days

Results: At the end of 4 weeks, body weight of rats were significantly increased ( $\mathrm{p}$ <0.05). Maximum weight gain was seen in control group whereas weight gain was least in O.S. $200 \mathrm{mg} / \mathrm{kg}$ group ( $\mathrm{p}>0.05$ ). Decrease in body weight was seen in metformin group. Abdominal circumference of rats also showed similar pattern $(p>0.05)$. OS 200 caused significant reduction in serum LDL levels $(p<0.05)$ and significant rise of serum HDL levels ( $\mathrm{p}<0.05)$ as compared to control group. Metformin also favourably affected the lipid profile and its effects were not significantly different from effects of OS 200 ( $p>0.05$ ).

Conclusions: Present study revealed that Ocimum Sanctum caused significant reduction in serum lipid levels in high fat diet fed diabetic rats. Metformin also exhibited antihyperlipidaemic activity. So, it is concluded that OS or metformin alone or in combination could be a novel adjunct to diet and life style modification for the management of dyslipidaemia in type 2 diabetes. Further studies are required to confirm the antidyslipidaemic activities of individual phytoconstituents of Ocimum sanctum.
\end{abstract}

Keywords: High fat diet, Lipid profile, Metformin, Ocimum sanctum, Rats

\section{INTRODUCTION}

Today's life style with high fat diet and less physical activity plays a significant part in development of dyslipidaemia and cardiovascular diseases. ${ }^{1,2}$ Studies have invariably concluded that unfavourable lipid profile serves an important risk factor for development of macrovascular complications in type 2 diabetes mellitus. ${ }^{3,4}$ So, there is always need of a safer yet effective drug for diabetic dyslipidaemia to decrease cardiovascular disease in individual at risk.

Herbs and phytochemicals, most of the times, are the sources of new therapeutic interventions. Majority of them act as antioxidants, hypoglycaemics or antihyperlipidaemics. ${ }^{5,6}$ Ocimum sanctum (OS) is a plant of family Lamiaceae found throughout India and has been used as a treatment of several ailments by the people in 
various countries. It has been concluded that $2 \%$ of dried OS leaf powder can affect serum lipid profile favourably in diabetic rats. ${ }^{7}$ Studies have also shown that OS leaf extract can also protect liver from heavy metals and prevent isoproterenol induced myocardial necrosis in rats. $^{8,9}$

Metformin is first line drug for newly diagnosed type 2 diabetes mellitus patients. ${ }^{10}$ It primarily inhibits gluconeogenesis and improves insulin sensitivity. ${ }^{10}$ It inhibits formation of complex I of mitochondrial electron transport chain and cellular energy is thus depleted. It also activates AMPK pathway. Active AMPK stimulates glycolysis and fatty acid oxidation and inhibits anabolic pathways like gluconeogenesis and fatty acid synthesis.10 Another important function of metformin is to reduce cardiovascular events in overweight people with type 2 diabetes mellitus. ${ }^{11}$ Lipid lowering effect of metformin has also been explored in various clinical trials. ${ }^{12-15}$ Statins' antihyperlipidaemic effects are ameliorated by metformin. ${ }^{16}$ Metformin monotherapy has also been shown to have effects in improving dyslipidaemia. ${ }^{12}$

Authors' previous study elucidated the dose related effects of OS and metformin on blood glucose levels in high fat diet fed diabetic rats. In the present study, role of OS and metformin for antihyperlipidaemic effects in different doses in high fat diet fed diabetic rats has been explored and compared.

\section{METHODS}

Approval by Institutional Animal Ethical Committee was taken before start of the study.

\section{Plant material}

The fresh leaves of Ocimum sanctum were arranged. Their authentication was done by a botanist from National Botanical Research Institute, Lucknow.

\section{Preparation of plant extract}

After being washed thoroughly with distilled water the leaves of Ocimum sanctum were dried in shade. Dried leaved were grounded to powder with the help of mortar and pestle. Now, leaves' powder $(500 \mathrm{gm})$ was soaked in $1500 \mathrm{ml} 99.99 \%$ ethanol (analytical grade), in a container at room temperature for one week with frequent stirring with a sterile glass rod. After one week, extract was filtered using Wattman's filter paper- no. 1 and the filtrate was transferred in a petri dish and left in shade for 3 days so that ethanol can be evaporated. The extract so obtained was dark green in colour with a characteristic smell. It was $50 \mathrm{~g}$ in weight when weighed in electronic weighing balance. Equal amount of distilled water i.e. $50 \mathrm{ml}$ had been added as vehicle. The extract was then transferred in aliquots of $1 \mathrm{ml}$ each and was stored at $4^{\circ} \mathrm{C}$ for further use. Dose of Ocimum sanctum was $100-200 \mathrm{mg} / \mathrm{kg}$ body weight based on previous studies. ${ }^{17}$

\section{Animals}

Total pf 30 male wistar rats $(100-150 \mathrm{gm})$ were obtained from CDRI, Lucknow (voucher specimen number pharmacology 62/12) and kept in the polycarbonate cages in institutional animal house under 12 hours day and night cycle, temperature of $22{ }^{\circ} \mathrm{C} \pm 2{ }^{\circ} \mathrm{C}$ and humidity of $45 \%$ $65 \%$. Animals were fed with a high fat diet (Dayal Industries Ltd, Lucknow) and water ad libitum.

All studies were performed after approval from Institutional Animal Ethics Committee, Era's Lucknow Medical College and as per the guidelines for animal care and experimentation by Committee for Purpose of Control and Supervision on Experiments on Animals (CPCSEA).

\section{Chemicals}

Streptozotocin and ethyl alcohol were obtained from Sigma Aldrich, USA. Metformin was obtained from Abbott India Ltd. Mumbai, India. High fat diet was procured from Hindustan Lever Limited through Dayal Industries, Lucknow.

\section{Statistical analysis}

Body weight and abdominal circumference parameters in the different groups were compared using Student paired ' $t$ ' test. Serum cholesterol, serum triglyceride, serum HDL, serum LDL, serum VLDL were compared using ANOVA along with Post-HOC Dunnett's T test. All analysis was done using SPSS 20.0 Version. P <0.05 was considered as significant.

\section{Study design}

High fat diet (HFD) was given to rats for 4 weeks. HFD was composed of $300 \mathrm{gm}$ concentrates, $350 \mathrm{corn}, 300 \mathrm{gm}$ beef tallow, $50 \mathrm{gm}$ vitamins, minerals and fibers. Calculations of HFD is $20 \%$ crude protein, $35 \%$ fat, $40 \%$ $\mathrm{CHO}$ (starch $35 \%, 5 \%$ sucrose) $5 \%$ vitamins and minerals and fibres. Metabolic energy of this diet is $5130 \mathrm{Kcal} / \mathrm{kg}$. $61 \%$ of this energy was from fat.

\section{Induction of type 2 diabetes mellitus}

After overnight fasting, diabetes was induced by single intra-peritoneal injection of streptozotocin $50 \mathrm{mg} / \mathrm{Kg}$. The animals were allowed to drink $5 \%$ glucose solution overnight to overcome drug-induced hypoglycemia. After a week's time for development of diabetes, diabetic rats (blood glucose above $250 \mathrm{mg} / \mathrm{dl}$ ) were used for further study. Amongst 30 rats, 6 could not be used as their blood sugar did not reach $250 \mathrm{mg} / \mathrm{dl}$. So, 24 rats were used for the study. Dose of O.S. was $100-200 \mathrm{mg} / \mathrm{kg}$ body weight .Dose of Metformin had been extrapolated from human dose $(1000 \mathrm{gm})$ to dose for rats. So, the dose of Metformin was $100 \mathrm{mg} /$ day. 
Diabetic rats were divided into groups of 6 each and treated as follows:

- Group 1: Control was given vehicle orally.

- Group 2: O.S. ethanolic extract $100 \mathrm{mg} / \mathrm{kg}$ body weight orally for 14 days.

- Group 3: O.S. ethanolic extract $200 \mathrm{mg} / \mathrm{kg}$ body weight orally for 14 days.

- Group 4: Metformin 100mg/day for 14 days.

\section{Measures of weight gain}

Body weight and abdominal girth was measured at the start and end of the study.

Abdominal circumference corresponds to visceral fat mass in rodents. It was assessed on the largest zone of the rat abdomen using a plastic non extensible measuring tape with an accuracy of $0.1 \mathrm{~cm}$.

\section{Measures of lipid profile}

Serum lipid profile was measured by using auto analyzers 18 in central laboratory of this Institute.

\section{RESULTS}

At the beginning of study, the mean weight of 30 rats was $127.50 \pm 8.47 \mathrm{gm}$. On day 15 , weight increased to $133.30 \pm 9.17 \mathrm{gm}$ and on day 30 , it increased to $141.04 \pm 9.89 \mathrm{gm}$. On applying Student paired ' $\mathrm{t}$ ' test, the increase in weight was highly significant $(\mathrm{P}<0.0001)$ on both day 15 and day 30 .

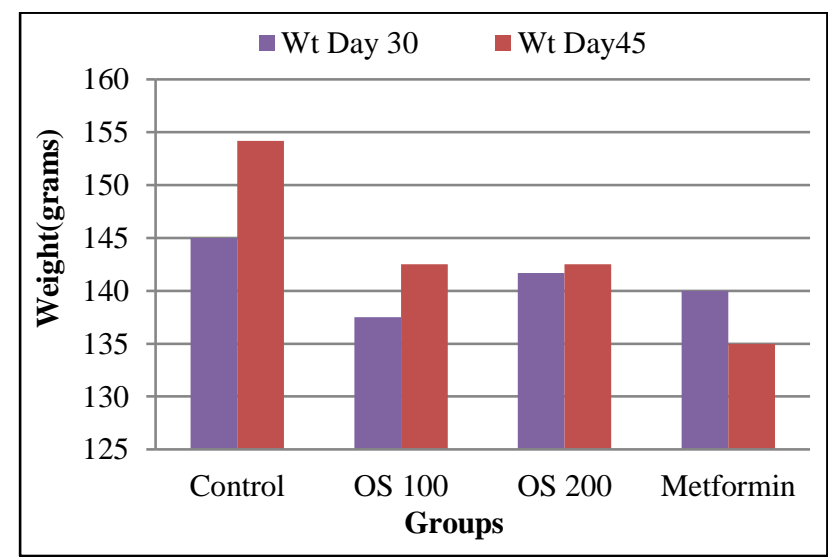

(OS 100-Ocimum sanctum 100mg/kg; OS 200- Ocimum sanctum $200 \mathrm{mg} / \mathrm{kg}$ )

\section{Figure 1: Effect of Ocimum sanctum on abdominal circumference in HFD fed diabetic rats.}

After induction of diabetes and continued HFD, there was an increase in weight at day 45 in control and Ocimum sanctum groups. The maximum weight gain was seen in control group $(9 \pm 2.5 \mathrm{~g})$ whereas weight gain was least in Ocimum sanctum $200 \mathrm{mg} / \mathrm{kg}$ group $(0.9 \pm 6.41)$ ( $\mathrm{p}>0.05)$. However, Metformin administration for 15 days caused a decrease in body weight ( $\mathrm{p}>0.05)$ as compared to OS 200 . (Figure 1).

At the beginning of study, the mean abdominal circumference $(\mathrm{AC})$ of 30 rats was $11.06 \pm 1.22 \mathrm{~cm}$. On day 15 , it increased to $11.81 \pm 1.38 \mathrm{~cm}$ and on day 30 , AC increased to $12.87 \pm 1.61 \mathrm{~cm}$. On applying Student paired ' $\mathrm{t}$ ' test, the increase in AC was highly significant $(\mathrm{P}<0.0001)$ on both day 15 and day 30 .

After induction of diabetes with continued HFD, there was an increase in AC at day 45 in control and Ocimum sanctum groups. The maximum gain in $\mathrm{AC}$ was seen in control group $(9 \pm 2.5 \mathrm{~g})$ whereas gain in $\mathrm{AC}$ was least in Ocimum sanctum $200 \mathrm{mg} / \mathrm{kg}$ group $(0.28 \pm 0.16)(\mathrm{p}>0.05)$. However, metformin administration for 15 days caused a decrease in AC ( $>0.05)$ as compared to OS 200 (Figure 2).

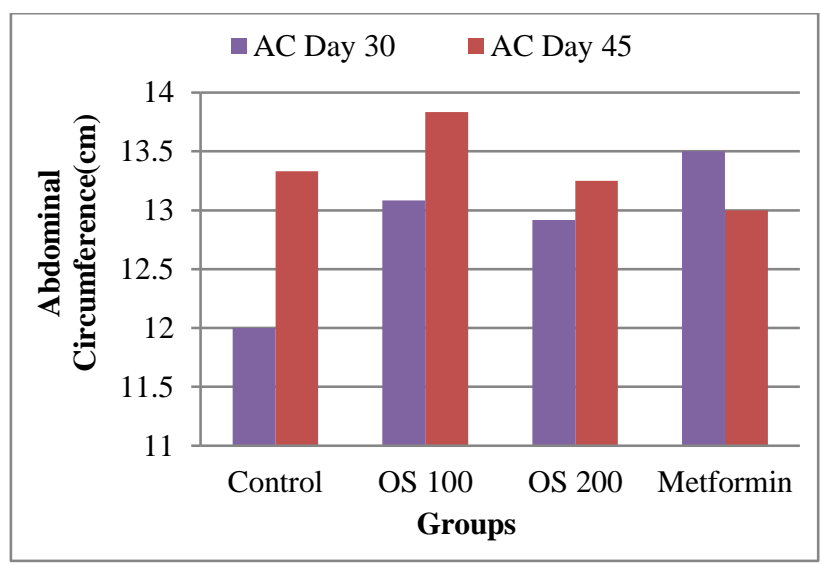

(OS 100-Ocimum sanctum $100 \mathrm{mg} / \mathrm{kg}$; OS 200-Ocimum sanctum $200 \mathrm{mg} / \mathrm{kg}$ )

\section{Figure 2: Effect of Ocimum sanctum on abdominal circumference in HFD fed diabetic rats.}

There was no significant difference in serum cholesterol levels at day-30 (after high fat diet without any drug treatment for 30 days in all 4 groups $(p>0.05)$. After induction of diabetes, there was an increase in total cholesterol levels after 15 days (day 45). The increase was highest in control group (23 \pm 3.9$)$ and lowest in metformin treated group (11.67 \pm 2.74$)$. However, no significant difference in total cholesterol levels was observed among the 4 groups at day $45(\mathrm{P}>0.05)$ (Table 1$)$.

There was no significant difference in serum triglyceride levels at day-30 (after high fat diet without any drug treatment for 30 days) in all 4 groups $(p>0.05)$. After induction of diabetes mellitus, there was an increase in triglyceride levels after 15 days (day 45), the increase was highest in control group $(44.5 \pm 10.97)$ and lowest in metformin treated group (16.5 \pm 1.12$)$. However, no significant difference was observed in triglyceride levels among the 4 groups at day $45(\mathrm{P}>0.05)$ (Table 1$)$.

There was no significant difference in serum HDL levels at day-30 (after high fat diet without any drug treatment for 
30 days) in all 4 groups ( $p>0.05)$. After induction of Diabetes Mellitus there was a decrease in serum HDL levels after 15 days (day 45) in control group and increase in other groups. The decrease in control group was least $(1.93 \pm 0.75)$ and highest in OS 200 treated group
$(4.56 \pm 0.22)(\mathrm{P}<0.05)$. The value of HDL in metformin treated group was also high and was not statistically significantly different from OS 200 treated group $(\mathrm{P}>0.05)$ (Table 1).

Table 1: Effect of Ocimum sanctum and metformin on lipid profile in high fat diet fed diabetic rats.

\begin{tabular}{|c|c|c|c|c|c|c|c|c|c|c|}
\hline \multirow[t]{2}{*}{ Groups } & \multicolumn{2}{|c|}{$\begin{array}{l}\text { Cholesterol } \\
\text { (mg/dl) }\end{array}$} & \multicolumn{2}{|c|}{$\begin{array}{l}\text { Triglycerides } \\
\text { (mg/dl) }\end{array}$} & \multicolumn{2}{|c|}{ LDL (mg/dl) } & \multicolumn{2}{|c|}{ HDL (mg/dl) } & \multicolumn{2}{|c|}{ VLDL (mg/dl) } \\
\hline & Day 30 & Day 45 & Day 30 & Day 45 & Day 30 & Day 45 & Day 30 & Day 45 & Day 30 & Day 45 \\
\hline Control & $\begin{array}{l}108.67 \\
\pm 6.51\end{array}$ & $\begin{array}{l}131 \\
\pm 9.60\end{array}$ & $\begin{array}{l}488.67 \\
\pm 226.38\end{array}$ & $\begin{array}{l}533.17 \\
\pm 237.5\end{array}$ & $\begin{array}{l}130.83 \\
\pm 17.5\end{array}$ & $\begin{array}{l}138 \\
\pm 18.48\end{array}$ & $\begin{array}{l}37.1 \\
\pm 3.18\end{array}$ & $\begin{array}{l}35.17 \\
\pm 3.93\end{array}$ & $\begin{array}{l}97.73 \\
\pm 45.25\end{array}$ & $\begin{array}{l}106.6 \\
3 \pm 47.7\end{array}$ \\
\hline OS 100 & $\begin{array}{l}109.67 \\
\pm 19.63 \\
\end{array}$ & $\begin{array}{l}132 \\
\pm 15.14\end{array}$ & $\begin{array}{l}405.67 \\
\pm 40.05\end{array}$ & $\begin{array}{l}432.83 \\
\pm 36.83\end{array}$ & $\begin{array}{l}128.5 \\
\pm 19.34\end{array}$ & $\begin{array}{l}100.17 \\
\pm 16.4 *\end{array}$ & $\begin{array}{l}35.1 \\
5 \pm 4.05\end{array}$ & $\begin{array}{l}39.87 \\
\pm 2.91\end{array}$ & $\begin{array}{l}81.13 \\
\pm 8.01\end{array}$ & $\begin{array}{l}86.57 \\
\pm 7.36\end{array}$ \\
\hline OS 200 & $\begin{array}{l}113.83 \\
\pm 8.59\end{array}$ & $\begin{array}{l}129.67 \\
\pm 3.73\end{array}$ & $\begin{array}{l}429.5 \\
\pm 59.73\end{array}$ & $\begin{array}{l}417.17 \\
\pm 57.32\end{array}$ & $\begin{array}{l}138.5 \\
\pm 5.59 \\
\end{array}$ & $\begin{array}{l}108 \\
\pm 15.26 *\end{array}$ & $\begin{array}{l}37.77 \\
\pm 3.34 \\
\end{array}$ & $\begin{array}{l}42.33 \\
\pm 3.56 \#\end{array}$ & $\begin{array}{l}85.9 \\
\pm 11.95\end{array}$ & $\begin{array}{l}83.43 \\
\pm 11.45 \\
\end{array}$ \\
\hline Metformin & $\begin{array}{l}114.83 \\
\pm 6.02\end{array}$ & $\begin{array}{l}126.5 \\
\pm 3.28\end{array}$ & $\begin{array}{l}484 \\
\pm 64.65\end{array}$ & $\begin{array}{l}467.5 \\
\pm 65.77\end{array}$ & $\begin{array}{l}128 \\
\pm 15.21\end{array}$ & $\begin{array}{l}124.5 \\
\pm 14.05\end{array}$ & $\begin{array}{l}39.88 \\
\pm 4.93\end{array}$ & $\begin{array}{l}41.67 \\
\pm 3.99\end{array}$ & $\begin{array}{l}96.8 \\
\pm 12.94\end{array}$ & $\begin{array}{l}93.5 \\
\pm 13.15\end{array}$ \\
\hline ANOVA & & & & & & & & & & \\
\hline $\mathrm{F}$ & 0.412 & 0.398 & 0.663 & 0.974 & 1.322 & 5.051 & 1.475 & 4.793 & 0.663 & 0.974 \\
\hline $\mathrm{P}$ & 0.746 & 0.756 & 0.585 & 0.424 & 0.295 & 0.009 & 0.252 & 0.011 & 0.585 & 0.424 \\
\hline
\end{tabular}

Values are in mean $\pm \mathrm{SD}, * \mathrm{P}<0.01$ as compared to control; $\mathrm{P}<0.05$ as compared to control

There was no significant difference in serum LDL levels at day-30 (after high fat diet without any drug treatment for 30 days) in all 4 groups. After induction of Diabetes Mellitus, there was an increase in serum LDL levels after 15 days (Day 45) in control group and decrease in other groups. The increase in control group was $7.17 \pm 0.7$ and lowest in OS $200 \mathrm{mg} / \mathrm{kg}$ treated group $(30.0 \pm 2.9)$. The LDL levels at day 45 were significantly lower $(\mathrm{P}<0.05)$ in rats treated with OS $200 \mathrm{mg} / \mathrm{kg}$ for 15 days. None was significant in comparison to metformin treated group. $(\mathrm{P}>0.05)$ (Table 1).

There was no significant difference in serum VLDL levels at day-30 (after high fat diet without any drug treatment for 30 days) in all 4 groups. After induction of Diabetes Mellitus, there was an increase in serum VLDL levels after 15 days (day 45) in control $(8.9 \pm 2.22)$ and Ocimum Sanctum $100 \mathrm{mg} / \mathrm{kg} \quad(7.44 \pm 0.65)$ groups whereas in Ocimum sanctum $200 \mathrm{mg} / \mathrm{kg}$ and metformin group $(3.3 \pm 0.21)$ a decrease in VLDL levels was observed. OS 200 showed maximum reduction $(2.47 \pm 0.50)$. However, no significant difference in serum VLDL levels was observed among the 4 groups at day 45 (Table 1).

\section{DISCUSSION}

Present study had shown that numerically Ocimum sanctum decreased the body weight and abdominal circumference of high fat diet fed diabetic rats, but results are not significant.
Panchal SK et al, reported that during 16 weeks on high fat diet, rats showed progressive increases in body weight, energy intake, abdominal fat deposition, and abdominal circumference along with impaired glucose tolerance, dyslipidemia, hyperinsulinemia, and increased plasma leptin and malondialdehyde concentrations. ${ }^{19}$ Cardiovascular signs included increased systolic blood pressure and endothelial dysfunction together with inflammation, fibrosis, hypertrophy, increased stiffness, and delayed repolarization in the left ventricle of the heart. The liver showed increased wet weight, fat deposition, inflammation, and fibrosis with increased plasma activity of liver enzymes. The kidneys showed inflammation and fibrosis, whereas the pancreas showed increased islet size. In comparison with other models of diabetes and obesity, this diet-induced model more closely mimics the changes observed in human metabolic syndrome. Their results of effect of high fat diet on body weight and abdominal circumference is in conformity with our results.

In present study, authors found that administration of Ocimum Sanctum causes significant reduction in serum cholesterol, serum triglycerides, serum LDL, serum VLDL levels as well as rise in level of serum HDL. Results of our study is in conformity with the study of Rai V et al, who reported that Ocimum sanctum powder supplementation causes a significant reduction in the levels of total cholesterol, LDL,VLDL and triglycerides. ${ }^{20}$ Gupta SK et al, reported hypocholestrolaemic and anti-oxidant activity of seed oil of Ocimum sanctum in diabetic rats. ${ }^{21}$ 
Present study is in conformity with the study of Halim E et al, who reported significant reduction in levels of cholesterol after administration of Ocimum sanctum. ${ }^{22}$ Suanarunsawat $\mathrm{T}$ et al, concluded that Ocimum decreased the high serum lipid profile and hepatic lipid content during high fat diet feeding in rats for seven weeks. ${ }^{7}$ Present study also exhibited this. The lipid lowering effect is probably due to the rise of bile acid synthesis using cholesterol as a precursor.

To the best of our knowledge, no previous study had reported the comparative evaluation of effect of Ocimum sanctum and metformin on serum lipid profile in HFD fed type 2 diabetes mellitus rats. In present study, authors found that minimum increase in weight was seen with OS 200 treated rats with continued HFD that was significantly different with control group. Metformin treated group showed weight reduction despite continued HFD exhibiting weight reducing effects of metformin. Effect of metformin on serum lipid profile was also explored. Metformin reduced serum total cholesterol, serum triglyceride and serum VLDL. Magnitude of reduction was not statistically different from that of OS 200. Numerical reduction of LDL and increase in HDL was also observed but did not approach that of OS. Xu T et al, concluded that metformin reduced levels of LDL-C and it is also having potential benefits in the prevention of cardiovascular disease. ${ }^{15}$ Lin et al, reported hypolipidaemic effect of Metformin monotherapy in statin naïve patients. ${ }^{12}$ Another study reported favourable effects of metformin on serum HDL and triglycerides levels, but no effect on serum LDL and total cholesterol in polycystic ovary syndrome patients. ${ }^{13}$ Similar findings were noted by Mehandiratta $R$ et al, where all serum lipids were favouably affected by metformin therapy and therefore the authors concluded that metformin could be useful in prevention of cardiovascular complications in women suffering from polycystic ovary syndrome in 6 months. ${ }^{14}$

The present study, therefore, concludes that Ocimum sanctum 200 and metformin both have almost similar antihyperlipidaemic activity and could be used alone or in combination in newly diagnosed diabetes mellitus patients to prevent cardiovascular complications. However, studies are required with combination therapy of OS and metformin as compared to alone against dyslipidaemia.

\section{CONCLUSION}

In present study, authors found that administration of Ocimum sanctum (100, 200mg) causes significant reduction in serum LDL level and significant rise in level of serum HDL (OS 200). Increase in serum total cholesterol with continued HFD was less as compared to control and it is minimum with metformin. OS 200 also showed minimum increase in serum triglycerides and VLDL level with continued HFD. The hypocholesterolemic effect of Ocimum sanctum appears to be due to the presence of active compounds such as
Eugenol, Alpha- Linolenic Acid, Omega-3 Fatty acid and their metabolite Eicosapentaenoic acid in its extract.

Metformin also exhibited antihyperlipidaemic activity. The results of effects of OS 200 and metformin on serum lipid profile were not significantly different with each other revealing almost similar effects of both on serum lipid profile.

Authors conclude that Ocimum sanctum improved lipid profile in high fat diet fed diabetic rats. This may be useful for treatment of diabetic over weight patients and dyslipidaemia. However, further research is required to advocate its clinical use. Metformin monotherapy improved dyslipidaemia and caused weight loss in HFD fed diabetic rats. So, it could be a safer approach to mitigate dyslipidaemia in newly diagnosed type 2 diabetes patients. In future studies, the isolated principles from leaves need to be evaluated in scientific manner using specific experimental animal models and clinical trials are to be done to understand the molecular mechanism of action, in search of lead molecule from Ocimum sanctum.

Funding: No funding sources

Conflict of interest: None declared

Ethical approval: The study was approved by the Institutional Ethics Committee

\section{REFERENCES}

1. Freedman JE. High-fat diets and cardiovascular disease: are nutritional supplements useful?. J Am Col Cardiol. 2003;41(10):1750-2.

2. Donahue R, Bloom E, Abbott R, Reed D, Yano K. Central obesity and coronary heart disease in men. Lancet. 1987 Apr 11;329(8537):821-4.

3. Schofield JD, Liu Y, Rao Balakrishnan P, Malik RA, Soran H. Diabetes dyslipidaemia. Diab Ther. 2016 Jun;7(2):203-19.

4. $\mathrm{Wu}$ L, Parhofer KG. Diabetic dyslipidaemia. Metabolism. 2014 Dec;63(12):1469-79.

5. Mahajan N, Rawal S, Verma M, Poddar M, Alok S. A phytopharmacological overview on Ocimum species with special emphasis on Ocimum sanctum. Biomed Preventive Nutr. 2013 Apr 1;3(2):185-92.

6. Pattanayak P, Behera P, Das D, Panda SK. Ocimum sanctum Linn. A reservoir plant for therapeutic applications: An overview. Pharmacognosy Reviews. 2010 Jan;4(7):95-105.

7. Suanarunsawat T, Songsak T. Antihyperglycaemic and antihyperlipidaemic effect of dietary supplement of white Ocimum Sanctum Linn before and after STZinduced diabetes mellitus. Int J Diab Metabolism. 2005;13:18-23.

8. Sharma MK, Kumar M, Kumar A. Ocimum Sanctum leaves extract provides protection against mercury induced toxicity in swiss albino mice. Indian J Exp Biol. 2002;40:1072-82.

9. Sood S, Narang D, Dinda AK, Maulik SK. Chronic oral administration of Ocimum Sanctum Linn 
augments cardiac endogenous antioxidants and prevents isoproterenol induced myocardial necrosis in rats. J Pharma Pharmacol. 2005;57:351-8.

10. Powers AC, D'Allessio D. Endocrine Pancreas and Pharmacotherapy of Diabetes Mellitus and Hypoglycemia. Brunton LL, Chabner BA, Knollman BJ. Goodman and Gillman's Pharmacological Basis of Therapeutics. 12th ed. Mac Graw Gill. 2011;1237-74.

11. American Diabetes Association. Standards of medical care for patients of diabetes mellitus. Diab Care. 2002;25 (suppl 1):s33-s49.

12. Lin SH, Cheng PC, Te Tu S, Hsu SR, Cheng YC, Liu YH. Effect of metformin monotherapy on serum lipid profile in statin-naïve individuals with newly diagnosed type 2 diabetes mellitus: a cohort study. PeerJ. 2018 Apr 12;6:e4578.

13. Karimzadeh MA, Eftekhar M, Taheripanah R, Tayebi N, Sakhavat L, Zare F. The effect of administration of metformin on lipid profile changes and insulin resistance in patients with polycystic ovary syndrome. Middle East Fertility Society Journal. 2007;12(3):1748.

14. Mehandiratta R, Jindal P, Takkar V, Kapila P, Kapila R. Effect of administration of metformin on lipid profile in patients with polycystic ovary syndrome after six months of treatment. Int J Med Res Prof. 2016;2(4):66-9.

15. $\mathrm{Xu}$ Tao, Brandmaier S, Messias AC, Herder C, Draisma HHM, Demirkan A et al. Effect of metformin on metabolic profiles and LDL cholesterol in patients with type 2 diabetes. Diab Care. 2015;38(10):1858-67.

16. Kashi Z, Mahrooz A, Kianmehr A, Alizadeh A. The role of metformin response in lipid metabolism in patients with recent-onset type 2 diabetes: HbA1c level as a criterion for designating patients as responders or nonresponders to metformin. PloS One. 2016 Mar 15;11(3):e0151543.
17. Caroline J, Vaidyanathan R, Rameshkumar G. Immunomodulatory activity of aqueous extract of Ocimum Sanctum in rat. Int $\mathbf{J}$ Pharmaceut Biomed Res. 2011;2(1):33-8.

18. Devi R, Sharma DK. Hypolipidemic effect of different extracts of Clerodendron colebrookianum Walp in normal and high-fat diet fed rats. J Ethnopharmacol. 2004 Jan 1;90(1):63-8.

19. Panchal SK, Poudyal H, Iyer A, Nazer R, Alam MA, Diwan V et al. High-carbohydrate, high-fat-dietinduced metabolic syndrome and cardiovascular remodeling in rats $\mathrm{J}$ Cardiovasc Pharmacol. 2011 May; 57(5):611-24.

20. Rai V, Iyer U, Mani UV, Effect of Tulsi (Ocimum Sanctum) leaf powder supplementation on blood sugar levels, serum lipids \& tissue lipids in diabetic rats. Plant Foods Hum Nutr. 1997;50(1):9-16.

21. Gupta SK, Prakash J, Srivastava S. Validation of traditional claim of Tulsi, Ocimum Santum Linn. as a medicinal plant. Indian J Experimen Biol. 2002;4:16573.

22. Halim E, Rao M, Jamil K. Hypoglycaemic, hypolipidaemic and antioxidant properties of Tulsi (Ocimum Sanctum linn) on streptozotocin induced diabetes in rats. Indian $\mathrm{J} f \mathrm{Clin}$ Biochem. 2001;16(2):190-4.

23. Nagai J, Takano M. Molecular aspects of renal handling of aminoglycosides and strategies for preventing the nephrotoxicity. Drug Metab Pharmacokinetics. 2004;19(3):159-70.

Cite this article as: Mishra S, Ahmed QS, Sayedda K. Comparative evaluation of the effect of Ocimum sanctum and metformin on serum lipid profile in high fat diet fed diabetic rats. Int J Basic Clin Pharmacol 2019;8:589-94. 